\title{
Economic impact of fluctuations in oilsardine landings in India
}

\author{
N. ASWATHY ${ }^{1}$, R. NARAYANAKUMAR ${ }^{2}$, SHYAM S. SALIM ${ }^{1}$, PRATHIBHA ROHIT $^{3}$ \\ AND A. GOPALAKRISHNAN ${ }^{1}$ \\ ${ }^{1}$ ICAR-Central Marine Fisheries Research Institute, Kochi - 682 018, Kerala, India \\ ${ }^{2}$ Madras Research Centre of ICAR-Central Marine Fisheries Research Institute, 75, Santhome High Road \\ Chennai - 600 028, Tamil Nadu, India \\ ${ }^{3}$ Mangalore Research Centre of ICAR-Central Marine Fisheries Research Institute, Mangalore - 575001 \\ Karnataka, India \\ e-mail:aswathy.icar@gmail.com
}

\begin{abstract}
The Indian oilsardine Sardinella longiceps (Valenciennes, 1847) is a significant contributor to the marine fisheries economy of India. The species showed wide fluctuations in landings in the past and during recent years, the decline in landings is an issue of concern for sustainable harvest of the resourcee specially in the context of climate change regime. The paper analysed the economic impacts of fluctuations in oilsardine landings in terms of gross earnings realised at landing centre and retail levels; inflation in the domestic markets and external trade during the 2000-2018 period. The analysis indicated that the decline in landings was more in the state of Kerala as compared to all India landings. The inflation at point of first sales (landing centre level) was more during 2000-09 period whereas at retail market level inflation was highest during 2010-18. The inflationary pressure on domestic consumers in Kerala was more during 2010-18 period. The growth in external trade of sardines was in tune with the Indian oilsardine landings in the country.
\end{abstract}

Keywords: External trade, Fluctuations, Growth, Indian oilsardine, Inflation, Instability

\section{Introduction}

The Indian oilsardine plays a vital role in meeting the nutritional requirement of countries across the world (Isaacs, 2016). Besides being a cheap source of protein in human diet, it is a highly preferred raw material in the fish meal industry across the globe accounting for $16 \%$ share among the various resources used for preparation of fish meal (Barlow, 2000). The other non-food uses include production of aquafeed and poultry feed or as bait in capture fisheries (Rohit et al., 2018). Apart from consumption in fresh form, a part of the Indian oilsardine catch is also used in dry fish trade (Shyam et al., 2016).

Oilsardine fisheries had shown wide fluctuations across the globe and anthropogenic as well as environmental factors are assumed to influence the landings (Rohit et al., 2018). In India, oilsardine forms a major resource in the south-west coast of India. However, it is distributed all along the west coast and along major part of the east coast. The share of oilsardine to the marine fish production in India varied from 2 to $33 \%$ in various years during 1962 to 2015 (Rohit et al., 2018). Pillai et al. (2003), Abdussamad et al. (2015) and Pravin and Meenakumari (2016) analysed the trends in oilsardine landings in India. The sardine economy in Kerala and the impact of catch decline on the traditional fishers in Kerala was studied by Shyam et al. (2015; 2017).
Rohit et al. (2018) discussed the causes of fluctuations in oilsardine landings, distribution, marketing channels and socio-economic factors in India and Kripa et al. (2018) analysed the factors causing the decline in oilsardine landings along Kerala. Balan and Sathianandan (2007) estimated the maximum sustainable yield (MSY) of oilsardine in Kerala. The population and stock structure of oilsardine were studied by Rohit and Baht (2006), Sebastian et al. (2017), Sukumaran et al. (2016) and Rohit et al. (2018).

Among the Indian maritime states, Kerala has always been the major producer of oilsardine and the average annual landings in Kerala pegged at 0.58 million $t$ during 2001 to 2010 (Pillai et al., 2003, Kripa et al., 2018). Oilsardine is a highly preferred table fish in Kerala and Karnataka, whereas in other major oilsardine producing states like Maharashtra, Gujarat and east coast states it is considered as a low value bycatch. In Kerala, during times of acute scarcity, consignments of oilsardine are procured from other coastal states like Karnataka, Goa, Maharashtra, Tamil Nadu and Andhra Pradesh (Das et al., 2013; Shyam et al., 2015; Roul et al., 2016) and also imported from other countries such as Oman (Prakasan et al., 2015).

The steep decline in oilsardine landings in recent past is a critical issue of concern both for the direct consumers 
as well as industries dependent heavily on the fish either for the preparation of value added products or as a raw material for production of fish oil and fish meal.The decline in the catch has had serious implications on the marine fisheries economy as well as on the livelihood security of small scale fishers in the country. Aswathy and Narayanakumar (2017) reported that, the growth in the value of oilsardine landings in India exceeded the growth in volume of landings during 1995-2014 period. The total economic loss incurred to the fishermen due to the decline in oilsardine catch in Kerala State alone was to the tune of ₹234.42 crores during 2015 (Shyam et al., 2017). In this backdrop, this study focused on the impact of fluctuations in oilsardine landings on the marine fisheries economy of the country in terms of gross earnings at landing centre and retail levels, inflation in domestic markets and external trade. Since oilsardine is the most preferred fish for consumption in fresh condition in Kerala, the inflationary pressures of catch fluctuations on the domestic markets in Kerala was also analysed.

\section{Materials and methods}

Secondary data on annual landings and price of oilsardine for the past two decades from 2000 to 2018 were collected (Sathiadhas and Kanagam, 2000; Sathiadhas and Hassan, 2002; Sathiadhas et al., 2012; CMFRI, 2012, 2013, 2014, 2015, 2016. 2017, 2018, 2019). The statistics for external trade of oilsardine during the period from 2000 to 2018 were collected from Marine Products Export Development Authority (MPEDA) and UN Comtrade Database (comtrade.un.org.). The various parameters were calculated using the following methods:

\section{a) Growth in oilsardine landings and gross value}

The growth in landings and gross value of oilsardine wereestimated using compound annual growth rate (CAGR):

$$
\mathrm{Y}=a b^{\mathrm{t}}
$$

where $\mathrm{Y}$ is the annual landings in tonnes; $\mathrm{t}=$ time

$$
\text { CAGR }=(\text { Antilog b-1) } \times 100
$$

\section{b) Fluctuations in landings and gross value}

The fluctuations in landings of oilsardine was calculated using Coppock's instability index (Coppock, 1962, Kaur and Singhal, 1988, Shende et al., 2011).

Coppock's instability index $=\sqrt{\log V-1}) \times 100$

where, $\log v=\frac{\sum_{i=1}^{n}\left[\log \frac{X_{t+1}}{X_{t}}-m\right]^{2}}{N-1}$
$\mathrm{X}_{\mathrm{t}}=$ Quantity of landings in year $\mathrm{t}$; $\mathrm{N}=$ No. of years; $\mathrm{m}=$ Arithmetic mean of the difference between the logs of $\mathrm{X}_{\mathrm{t}}$ and $\mathrm{X}_{\mathrm{t}+1}$ etc., $\log \mathrm{V}=$ logarithmic variance of annual landings or gross earnings at landing centre/retail levels

c) Fluctuations in landings and inflationary pressure on domestic consumers

The inflation in oilsardine prices at landing centre as well as retail levels were calculated based on the price indices calculated for the past two decades. The fish price index (FPI) can trace the extent to which the seafood is becoming more or less expensive (Tveteras et al., 2012). The price indices of oilsardine were calculated based on annual average landing centre and retail prices during 2010-2018 with 2011 as base year.

$$
\mathrm{I}_{\mathrm{t}}=\left(\mathrm{P}_{\mathrm{t}} / \mathrm{P}_{\mathrm{b}}\right)^{*} 100
$$

where $I_{t}$ is the price index in year $t ; P_{t}$ is the price in year $t$ and $\mathrm{P}_{\mathrm{b}}$ is the base period price.

$$
\text { Annual inflation rate }=\frac{\left(I_{t+1}-I_{t}\right)}{I_{t}} * 100
$$

\section{Results and discussion}

Growth in oilsardine landings and gross earnings at landing centre and retail market levels

The oilsardine landings in India increased from 3.67 lakh $\mathrm{t}$ in 2000 to 4.88 lakh $\mathrm{t}$ in 2010, further increased to 7.2 lakh $\mathrm{t}$ in 2012 and then drastically declined to 1.55 lakh $\mathrm{t}$ in 2018. The gross value realised at landing centre level increased from ₹380 crores in 2000 to ₹ 1247 crores in 2010 and then declined to ₹960 crores in 2018. During 2012, when highest landings was recorded, the gross value of the catch at landing centres was ₹2233 crores. Its share in the gross value increased from $3.66 \%$ in 2000 to $12.03 \%$ in 2010 and then declined to $2.64 \%$ in 2018 . At retail level, gross value of oilsardine increased from ₹956 crores in 2000 to ₹2276 crores in 2010 which then declined to ₹1674 crores in 2018 and the share in gross value declined from $10.05 \%$ to $2.95 \%$ during $2010-18$ period. Analysis of the growth and fluctuations in the landings and gross value realised for oilsardine indicated that there was positive growth in landings and gross value during 2000-09 period whereas the growth was negative during 2010-18 period. At retail level also, the gross value realised was positive during $2000-09$ period and the growth was negative during 2010-18 (Table 1).

Results of the present study clearly implied that there was a sharp decline in oilsardine landings in the country during 2010-18 period. During 2010-18, the decline in 
Table 1. Growth in landings and value of oilsardine in India (2000-2018)

\begin{tabular}{llll}
\hline Particulars & Landings $(\mathrm{t})$ & LCV (₹crores) & RTV (₹crores) \\
\hline 2000 & $367537(13.85)$ & $380(3.66)$ & $956(4.22)$ \\
2010 & $488204(14.70)$ & $1247(12.03)$ & $2276(10.05)$ \\
2018 & $155000(4.44)$ & $930(2.64)$ & $1674(2.95)$ \\
CAGR (2000-2009) & 3.87 & $10.95 * *$ & $9.00 * *$ \\
CAGR (2010-18) & $-14.45^{* *}$ & -3.200 & -3.82 \\
\hline
\end{tabular}

LCV: Gross value at landing centre level; RTV: Gross value at retail level

Oilsardine landing data source: Annual reports of ICAR-CMFRI

${ }^{* *}$ Indicates significance at $1 \%$ level

Figures in parenthesis indicate percentage to overall landings or gross value

gross value realised at landing centre and retail levels were less when compared to the sharp decline in landings due to increase in price both at landing centre and retail levels.

Several theories have been postulated for the decline in oilsardine landings in the past decades and has been discussed in detail by Rohit et al. (2018). The economic impact of the decline on the gross earnings of various categories of fisherfolk has however not been addressed in most of the earlier studies. The percentage of oilsardine in non-mechanised sector declined from $16 \%$ in 2007 to 6\% in 2015 in Kerala (CMFRI, 2016; Rohit et al., 2018; Kripa et al., 2018). Shyam et al. (2017) reported that the reduction in oilsardine landings resulted in reduced number of employment opportunities for the traditional fishers in Kerala during 2012-15 period and the average wage loss during the year 2015 was ₹104.6 crores. A disaggregated analysis of the socio-economic impact of the decline in oilsardine landings on different categories of fisherfolk at regional and national level is essential to assess the impact of the decline on livelihood security of traditional fisherfolk who largely depend on this small pelagic fish.

\section{Fluctuations in landings and gross value}

The fluctuations in landings and gross value were more during 2010-18 period than the previous decade (Table 2). The highest fluctuation was shown by gross value realised at landing centres (point of first sales) with instability index of 48.94 than the fluctuations at retail level. The volatility in gross earnings at point of first sales indicated the prevalence of unstable prices to the fisherfolk (Sathiadhas et al., 2011).
Fluctuations in oilsardine landings and inflationary pressure on domestic consumers

The inflation during 2000-2009 and 2010-2018 period were analysed by constructing price indices based on average landing centre and retail prices in Kerala as well as all India average prices (Table 3 ). The inflation was more at landing centre level compared to retail markets at all India level during 2000-18 period whereas in Kerala the inflation rate was more at the retail markets during 2010-18 period indicating the domestic consumers in Kerala were worst affected due to the decline in oilsardine landings. The oilsardine landings in Kerala declined from 2.4 lakh $\mathrm{t}$ in 2000 to $77,093 \mathrm{t}$ in 2018 . The annual average decline during $2010-18$ period was $19.82 \%$ (Table 4$)$.

The increasing price of oilsardine will have serious implications for the domestic consumers and also nonfood uses in the country. Oilsardine is a highly preferred food fish especially among the coastal population in Kerala and Karnataka. Moreover, with the expansion in the aquaculture and poultry sectors, the use of oilsardine for non-food purposes mostly as fishmeal, the main protein source in poultry as well as aquafeed has also increased. In Kerala, $90 \%$ of the catch landed is utilised in fresh form and oilsardine formed nearly $30 \%$ of all fish consumed. The average monthly consumption demand for oilsardine in Kerala was estimated at 0.19 lakh $t$ (Shyam et al., 2015) which means that at least 2-2.5 lakh t of oilsardine are required annually for meeting the domestic consumption demand for the state of Kerala alone. This along with the consumption demand in other states and requirement in non-food sectors points to a huge supply-demand gap

Table 2. Fluctuations in oilsardine landings and gross value (Coppocks Instability Index-CII)

\begin{tabular}{lll}
\hline Particulars & CII (2000-2009) & CII (2010-2018) \\
\hline Landings & 20.21 & 46.92 \\
Gross value at landing centres & 10.01 & 48.94 \\
Gross value at retail level & 17.33 & 45.32 \\
\hline
\end{tabular}


Table 3. Price indices and annual inflation rates for oilsardine at landing centre and retail markets in Kerala and India (base 2011=100)

\begin{tabular}{|c|c|c|c|c|c|c|c|c|}
\hline \multirow{2}{*}{ Years } & \multicolumn{4}{|c|}{ India } & \multicolumn{4}{|c|}{ Kerala } \\
\hline & LCPI & Annual inflation rate & RTPI & Annual inflation rate & LCPI & Annual inflation rate & RTPI & Annual inflation rate \\
\hline 2000 & 38.27 & & 53.07 & & 35.90 & & 35.21 & \\
\hline 2001 & 56.48 & 47.59 & 61.47 & 15.82 & 38.46 & 7.14 & 36.62 & 4.00 \\
\hline 2002 & 50.19 & -11.15 & 59.66 & -2.94 & 38.46 & 0.00 & 38.03 & 3.85 \\
\hline 2003 & 52.27 & 4.16 & 61.49 & 3.07 & 38.46 & 0.00 & 39.44 & 3.70 \\
\hline 2004 & 54.81 & 4.86 & 64.69 & 5.21 & 41.03 & 6.67 & 42.25 & 7.14 \\
\hline 2005 & 57.41 & 4.73 & 65.31 & 0.95 & 38.46 & -6.25 & 42.25 & 0.00 \\
\hline 2006 & 60.10 & 4.70 & 73.92 & 13.20 & 66.67 & 73.33 & 46.48 & 10.00 \\
\hline 2007 & 56.61 & -5.81 & 73.72 & -0.28 & 74.36 & 11.54 & 50.70 & 9.09 \\
\hline 2008 & 76.24 & 34.67 & 76.75 & 4.11 & 79.49 & 6.90 & 54.93 & 8.33 \\
\hline 2009 & 90.10 & 18.18 & 90.18 & 17.49 & 84.62 & 6.45 & 60.56 & 10.26 \\
\hline 2010 & 94.61 & 5.00 & 95.12 & 5.49 & 87.18 & 3.03 & 66.20 & 9.30 \\
\hline 2011 & 100.00 & 5.70 & 100.00 & 5.13 & 100.00 & 14.71 & 100.00 & 51.06 \\
\hline 2012 & 114.81 & 14.81 & 104.08 & 4.08 & 105.13 & 5.13 & 112.68 & 12.68 \\
\hline 2013 & 107.41 & -6.45 & 116.33 & 11.76 & 112.82 & 7.32 & 115.49 & 2.50 \\
\hline 2014 & 159.26 & 48.28 & 146.94 & 26.32 & 115.38 & 2.27 & 123.94 & 7.32 \\
\hline 2015 & 181.48 & 13.95 & 171.43 & 16.67 & 166.67 & 44.44 & 176.06 & 42.05 \\
\hline 2016 & 214.81 & 18.37 & 183.67 & 7.14 & 141.03 & -15.38 & 133.80 & -24.00 \\
\hline 2017 & 209.15 & -2.64 & 203.76 & 10.93 & 138.46 & -1.82 & 138.03 & 3.16 \\
\hline 2018 & 222.22 & 6.25 & 220.41 & 8.17 & 179.49 & 29.63 & 169.01 & 22.45 \\
\hline
\end{tabular}

LCPI: Landing centre price index; RTPI: Retail price index

Table 4. Growth in oilsardine landings, landing centre and retail values in Kerala

\begin{tabular}{llll}
\hline Years & Landings $(\mathrm{t})$ & LCV (₹crores) & RTV (₹crores) \\
\hline 2000 & $241411(39.96)$ & $338(13.86)$ & $604(14.14)$ \\
2010 & $259341(42.64)$ & $882(23.19)$ & $1219(22.08)$ \\
2018 & $77093(12.01)$ & $540(4.99)$ & $925(6.18)$ \\
CAGR(2000-09) & 1.85 & $11.02^{* *}$ & $5.75^{* *}$ \\
CAGR(2010:18) & $-19.82^{* *}$ & $-13.08^{* *}$ & $-12.15^{* *}$ \\
\hline
\end{tabular}

LCV: Gross value at landing centre level; RTV: Gross value at retail level

Oilsardine landing data source: Annual reports of ICAR-CMFRI

** Indicates significance at $1 \%$ level

Figures in parenthesis indicate percentage to overall landings or gross value

for oilsardine in the country. The decline in oilsardine landings was more in the state of Kerala when compared to the decline at all India level during 2010-18 period and this led to price escalation in the retail markets.

Fluctuations in oilsardine landings and impact on external trade

Sardine is not a major item in the marine export basket of India. The export of sardines (all species together) was taken as a proxy for analysing the impacts of decline in oilsardine catch on external trade, as separate statistics on oilsardine exports is not available. Sardines are exported to several countries including USA, Kenya, Nigeria, Tanzania, New Zealand, Sri Lanka, Bahrain, UAE, Kuwait, Zimbabwe, Netherlands, Japan, China, Bangladesh, Canada, Quatar, Australia, Vietnam and Malaysia. It is exported as whole individual quick frozen (IQF), Sardine peera, sardine curry, surimi, canned sardine, canned sardine in tomato sauce, canned sardine in vegetable oil, chilled sardine and as dried fish meal. The export of sardines increased from a mere $80 \mathrm{t}$ in 2000 to $59,791 \mathrm{t}$ in 2012. Thereafter, it registered a decline and reached $1391 \mathrm{t}$ in 2018. The share of exports as a percentage of overall oilsardine landings was less than $1 \%$ for most of the years and the highest share was in 2012 (8.3\%) followed by 2011 (4.5\%) (Fig. 1). The average unit value realised in the export market was also less than that realised in domestic markets of the country, suggesting better preference in the domestic sector as compared to export market. The average unit value in the export market increased from ₹29 per kg during 2000-09 to ₹60 per kg during 2010-18 period. 


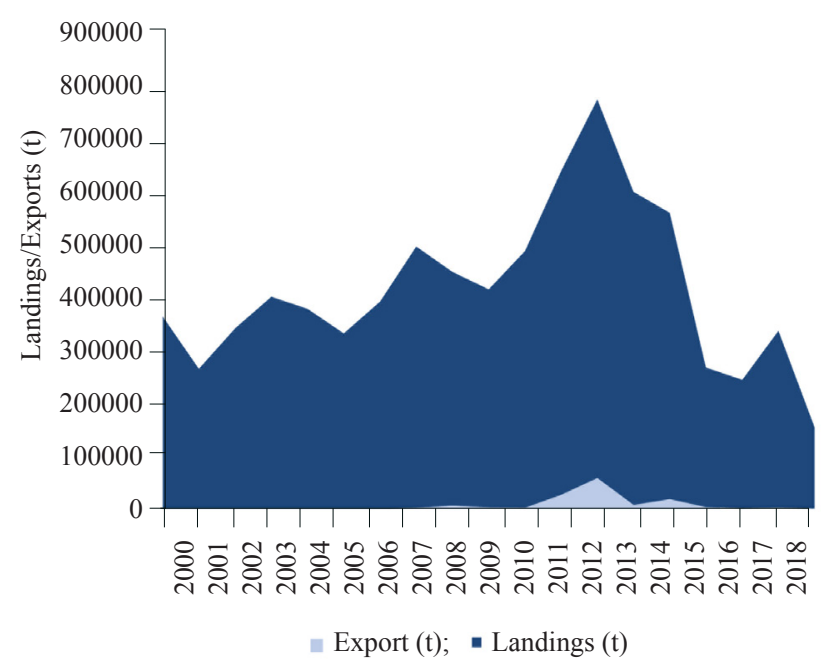

Fig. 1. Sardine exports vs oilsardine landings in India (2000-18)

The export of sardines during 2000-09 period was $1,749 \mathrm{t}$ and 14,444 $\mathrm{t}$ during 2010-18 period. In terms of quantity and value, the exports increased by $64.55 \%$ and $63.84 \%$ respectively during $2000-09$ period and declined to 25.21 and $17.51 \%$ respectively during $2010-18$. The imports showed considerable growth during 2010-18 (Table 5). The highest export $(59,791 \mathrm{t})$ and the lowest imports $(548 \mathrm{~kg}$ ) were reported in the year 2012 coinciding with the highest oilsardine landings in the country. The exports drastically declined to 1,391 t in 2018 when lower landings too were recorded clearly indicating that the external trade of sardines is in tune with the oilsardine landing trends in the country.

The decline in oilsardine landings observed in recent years are expected to recover as happened during the previous boom and bust cycles. However considering the vulnerability of the species to climate change and other environmental fluctuations, management strategies are essential for the sustainable exploitation of this small pelagic species, considering the widespread nutritional and economic implications on the traditional and marginal coastal fishers. As it is mostly the traditional sector (especially in Kerala) who are dependent on this small pelagic fish, a comprehensive analysis on the socioeconomic impact of decline in oilsardine landings on the livelihood security of traditional fisherfolk is highly desired. The domestic consumers and fishmeal industries are the two most important and major sectors that take up the oilsardine landed in the country. The present study has clearly shown that reduction in catch has seriously affected the domestic consumers by way of price hike in retail markets. Oilsardine is one of the major component in the aggregate marine fish landings and consumption of the country. Hence a comprehensive analysis of the direct and indirect impacts of the catch decline on the traditional fishing sector, domestic consumers, fish meal and aquafeed industry are essential for developing policies for the management and sustainable exploitation of the resource ensuring livelihood security of fishers and food security to domestic consumers.

Table 5. Growth in external trade of sardines in India

\begin{tabular}{lllll}
\hline Years & Export $(\mathrm{t})$ & Export $(\$)$ & Import $(\mathrm{t})$ & Import $(\$)$ \\
\hline $2000-09$ & 1749 & 1137664 & 1570 & 29056 \\
$2010-18$ & 14444 & 8978973 & 8979 & 689626 \\
CAGR $(2000-09)$ & $64.55^{* *}$ & $63.83^{* *}$ & 48.95 & 31.48 \\
CAGR $(2010: 18)$ & -25.21 & -17.51 & 117.68 & 71.39 \\
\hline
\end{tabular}

**Indicates significance at $1 \%$ level

\section{References}

Abdussamad, E. M., Ganga, U., Koya, K. P. S., Prakasan, D. and Gireesh, R. 2015. Ring seine fishery of Kerala: An overview. Mar. Fish. Inf. Serv. T\&E Ser., (225): 3-7.

Aswathy, N. and Narayanakumar, R. 2017. Inflation in marine fish price in India: Analysis using ex-vessel price indices. Int. J. Agric. Innov. Res., 5: 677-679.

Aswathy, N., Shyam S. Salim, Vipinkumar, V. P. and Naraayanakumar. R. 2017. Price behaviour, marketing channels and efficiency of marine fish marketing in Karnataka. Mar. Fish. Inf. Serv. T\&E Ser., 232: 15-17.

Balan, K. and Sathianandan, T. V. 2007. An assessment of ring seine fishery in Kerala through surplus production model. Indian J. Fish., 54: 135-140.
Barlow, S. 2000. Fishmeal and fish oil: Sustainable feed ingredients for aquafeeds. Global Aquac. Adv., 3(2): 85-88.

CMFRI 2011. Annual report 2010-11. ICAR-Central Marine Fisheries Research Institute, Kochi, Kerala, India, 166 pp.

CMFRI 2012. Annual report 2011-12. ICAR-Central Marine Fisheries Research Institute, Kochi, Kerala, India, 190 pp

CMFRI 2013. Annual report 2012-13. ICAR-Central Marine Fisheries Research Institute, Kochi, Kerala, India, 186 pp.

CMFRI 2014. Annual report 2013-14. ICAR-Central Marine Fisheries Research Institute, Kochi, Kerala, India, 274 pp.

CMFRI 2015. Annual report 2014-15. ICAR-Central Marine Fisheries Research Institute, Kochi, Kerala, India, 353 pp. 
CMFRI 2016. Annual report 2015-16. ICAR-Central Marine Fisheries Research Institute, Kochi, Kerala, India, 296 pp.

CMFRI 2017. Annual report 2016-17. ICAR-Central Marine Fisheries Research Institute, Kochi, Kerala, India, 292 pp.

CMFRI 2018. Annual report 2017-18. ICAR-Central Marine Fisheries Research Institute, Kochi, Kerala, India, 186 pp

CMFRI 2019. Annual report 2018-19. ICAR-Central Marine Fisheries Research Institute, Kochi, Kerala, India, 320 pp.

Coppock, J. D. 1962. International economic instability: The experience after World War II. McGraw Hill Book Co., New York, USA.

Das, M., Prathibha Rohit, Maheshwarudu, G., Biswajit Dash and Ramanna. P. V. 2013. An overview of dry fish landings and trade at Visakhapatnam Fishing Harbour. Mar. Fish. Inf. Serv. T\&E Ser., 215: 3-7.

Isaacs Moenieba 2016. The humble sardine (small pelagic): Fish as food or fodder. Agric. Food Secur., 5(1): 27 pp.

Kaur, N. and Singhal, K.C. 1988. India's export instability. Margin, 21: 54-61.

Kripa, V., Mohamed, K. S., Shelton Padua, Jeyabaskaran, R. and Prema, D. 2019. Similarities between Indian oilsardine Sardinella longiceps Valenciennes 1847 and global sardine fisheries and its management. J. Mar. Biol. Ass. India, 61(1): 5-18

Kripa, V., Mohamed, K. S., Said Koya, K. P., Jeyabaskaran, R., Prema, D., Shelton Padua, Somy Kuriakose, Anilkumar, P. S., Preetha G. Nair, Ambrose, T. V., Dhanya, A. M., Abhilash, K. S., John Bose, Divya, N. D., Shara, A. S. and Vishnu, P. G. 2018. Overfishing and climate drives changes in biology and recruitment of the Indian oil sardine, Sardinella longiceps in South-eastern Arabian Sea, Front. Mar. Sci., 5:443. doi: 10.3389/ fmars.2018.00443.

MPEDA 2006. Statistics of marine products 2004. The Marine Products Export Development Authority, Ministry of Commerce and Industries, Govt. of India, 677 pp.

MPEDA 2012. Statistics of marine products 2010. The Marine Products Export Development Authority, Ministry of Commerce and Industries, Govt. of India, 677 pp.

Pillai, N. G. K., Ganga, U. and Jayaprakash, A. A. 2003. Indian oil sardine. In: Mohan Joseph, M. and Jayaprakash, A. A. (Eds.), Status of exploited marine fishery resources of India.ICAR-Central Marine Fisheries Research Institute, Kochi, Kerala, India, p. 18-24.

Ponnusamy, K. Ambasankar, K. and Ponniah, A. G., 2012. Production and marketing of fish meal in India - A study. Indian J. Fish., 59(1): 147-149.

Prakasan, D., Jinesh, P. T., Beni, N., Rema, K. V. and Ganga, U. 2015. Oil sardine from Oman enters fish markets of Kerala. Mar. Fish. Inf. Serv. T\&E Ser., 223\&224: 24-25.
Pravin, P. and Meenakumari, B. 2016. Purse seining in India-A review. Indian J. Fish., 63(3): 162-174. DOI: 10.21077/ijf 2016.63.3.50404-25.

Rohit, P. and Bhat, U. S. 2006. Sardine fishery with notes on the biology and stock assessment of oil sardine off MangaloreMalpe, J. Mar. Biol. Ass. India, 45(1): 61-73.

Rohit, P., Sivadas, M., Abdussamad, E. M., Margaret Muthu Rathinam, A., Said Koya, K. P., Ganga, U., Shubhadeep Ghosh, Rajesh, K. M. Mohammed Koya, K., Anulekshmi Chellappan, Mini, K. G., Grinson George, Roul, S. K., Surya, S., Sukumaran, Sandhya, Vivekanandan, E., Retheesh, T. B., Prakasan, D., Satish Kumar, M., Mohan, S., Vasu, R. and Supraba, V. (2018). Enigmatic Indian oil sardine: An insight. CMFRI Special Publication No. 130. ICAR-Central Marine Fisheries Research Institute, Kochi, Kerala, India, 156 pp.

Roul, S. K., Retheesh, T. B., Prakasan, D. and Abdussamad, E. M 2016. Oil sardine from Tamil Nadu in fish markets of Kerala. Mar. Fish. Inf. Serv. T\&E Ser., 229: 20.

Sathiadas, R., Narayanakumar, R. and Aswathy. N. 2011 Efficiency of domestic marine fish marketing in India - A macro analysis. Indian J. Fish., 58(4): 125-131.

Sathiadhas, R and Hassan, F. 2002. Product diversification and promotion of value added sea food products. Seafood Export J., 33(8\&9): 27-42.

Sathiadhas, R. and Kanagam, A. 2000. Distribution problems and marketing management of marine fisheries in India.. In: Pillai, V. N. and Menon, N. G. (Eds.), Marine fisheries research and management. ICAR-Central Marine Fisheries Research Institute, Kochi, Kerala, India, p. $858-875$.

Sathiadhas, R., Narayanakumar, R. and Aswathy, N. 2012. Marine fish marketing in India. ICAR-Central Marine Fisheries Research Institute, Kochi, Kerala, India, $276 \mathrm{pp}$.

Sathianandan, T. V. and Alagaraja, K. 1998. Spectral decomposition of the all India landings of oil sardine, mackerel and Bombay duck. Indian J. Fish., 45(1): 13-20.

Sebastian, W., Sukumaran, S., Zacharia, P. U. and Gopalakrishnan, A. 2017. Genetic population structure of Indian oil sardine, Sardinella longiceps assessed using microsatellite markers. Conserv. Gen.,18: 951-964. DOI: 10.1007/s10592-0170946-6.

Shende, N. V., Ganvir, B. N. and Thakare, S. S. 2011. Growth and instability of selected crops in Western Vidarbha, Int Res. J. Agric. Eco. Stat., 2(1): 19-27.

Shyam S. Salim, Mohamed, K. S., Safeena, P. K. and Remya, R. 2017. Effect of declining oil sardine landings on the livelihoods of traditional fishers in Kerala. J. Indian Fish. Ass., 44(2): 63-70. 
Shyam, S. Salim, Rahman, M., Ramees, M. and Bindu, A. 2015. Sardine economy of Kerala - Paradigms and perspectives. Int. J. Fish. Aquat. Stud., 2(6): 351-356.

Shyam, S. Salim, Rahman, M., Ramees, M. and Nashad, M. 2016. Economic analysis of fish drying units in Kozhikode, Kerala. Discov. Nature, 10(25): 1-8.

Sukumaran, S., Sebastian, W. and Gopalakrishnan, A. 2016. Population genetic structure of Indian oil sardine, Sardinella longiceps along Indian coast. Gene, 576(1): 372-378. doi: 10.1016/j.gene.2015.10.043.

Tveteras Sigbjorn, Frank Asche, Marc F. Bellemare, Martin D. Smith, Atle G. Guttormsen, Tveteras S., Asche, F., Bellemare, M. F., Smith, M. D., Guttormsen, A. G., AudunLem Kristin Lien and Stefania Vannuccini 2012. Fish is food - The FAO's Fish Price Index. PLoS ONE, 7(5): e36731. doi:10.1371/journal.pone.0036731. 